\title{
Pre-adoption market reaction to IFRS 9: A cross-country event-study
}

\author{
Enrico Onali $^{\text {a,+ }}$, Gianluca Ginesti ${ }^{\text {b }}$
}

a Bangor Business School, Bangor University, Hen Goleg, College Road, Bangor LL57 2DG, United Kingdom.

b Department of Economics, Second University of Naples, Corso Gran Priorato di Malta, Capua (CE) 81043, Italy.

${ }^{+}$Corresponding author: e.onali@bangor.ac.uk; Tel: +44(0)1248383650.

\begin{abstract}
We are the first to examine the market reaction to 13 announcement dates related to IFRS 9 for over 5,400 European listed firms. We find an overall positive reaction to the introduction of IFRS 9. The regulation is particularly beneficial to shareholders of firms in countries with weaker rule of law and a smaller divergence between local GAAP and IAS 39. Bootstrap simulations rule out the possibility that sampling error or data mining are driving our findings. Our main findings are also robust to confounding events and the extent of the media coverage for each event. These results suggest that investors perceive the new regulation as shareholder-wealth enhancing and support the view that stronger comparability across accounting standards of European firms is beneficial to international investors and outweighs the costs of poorer firm-specific information.
\end{abstract}

Keywords: financial instruments; IFRS 9; event study; international financial reporting standards 
"The FASB and IASB have heard the urgent call for an improved, converged approach to impairment of debt instruments. We are keenly interested in whether investors think this revised approach provides relevant and timely information about credit losses [...]".

Leslie Seidman (Chairman of FASB, 2010-2013), January 31, 2011

"IFRSs are primarily aimed at investors and creditors. And we really need to know what you - the primary users of financial statements - want."

Ian Mackintosh (Vice-chairman of IASB), August 5, 2011

\section{Introduction}

What does the market think about the new potential accounting regime for financial instruments (IFRS 9)? Do national characteristics of the country where the firm is domiciled affect investors' reaction? These questions are key to understanding the potential impact of the IFRS 9 adoption in the European Union (EU) on international investors. The replacement of IAS 39 with IFRS 9 is one of key topics in the agenda of International Accounting Standards Board (IASB). At the G-20 summits in 2009, world leaders called for improvements of IAS 39. The role of IAS 39 for financial stability has generated a lively debate even among academics (Laux and Leuz, 2009 and 2010; Barth and Landsman, 2010; Laux, 2012), because IAS 39 is widely considered to be a controversial accounting standard, largely due to its complexities (Armstrong et al., 2010; Paananen et al., 2012). Advocates of the reform claim that IFRS 9 reduces and simplifies the many rules in IAS 39, and increases cross-country comparability. Therefore, IFRS 9 should decrease the degree of asymmetric information, especially for international investors, and increase the value relevance of accounting data for investment decisions (Chen et al., 2013). Eventually, this should lead to lower cost of capital (Armstrong et al., 2010). Simplifying IAS 39 is a key innovation: Dichev et al. (2014) find that CFOs view favorably a reduction in the number of rules promulgated by standard setters, and support convergence between IFRS and U.S. GAAP. However, convergence could also be costly for investors, because of a decrease in the quality of firm-specific information (Ding et al., 2007), and a decrease in the comparability of financial accounts before and after the reform. Moreover, managers point out high costs of adoption and compliance for firms, and investor confusion (Dichev et al., 2014).

A better understanding of capital market outcomes of IFRS reporting is of fundamental importance to researchers, policy makers and regulators (Christensen et al., 2013). Despite the interest generated among policy makers and academics, it is unclear whether investors think that the current proposals for amendments of accounting for financial instruments incorporated in IFRS 9 are beneficial. Changes in accounting regulation cannot be considered independent of country-specific institutional characteristics (Leuz, 2010). For this reason, heterogeneities in the direction and magnitude of the reaction may exist due to a different legal framework and degree of law enforcement (La Porta et al., 1998; La Porta et al., 2006; Armstrong et al., 2010), and confidence in the rules of society (i.e. rule of law) across different countries in the EU. The degree of divergence between international accounting standards and local GAAP can also play a role, because the costs of convergence can be higher for countries with larger divergence between local accounting standards and international accounting standards (Ding et al., 2007). 
Regulatory reforms can be a way to extract wealth from competitors and to estimate the impact of new regulation it is often necessary to examine price reactions before the law is implemented (Stigler, 1971; Schwert, 1981). Recent papers in the accounting and finance literature have employed event study methodology to assess investors' perception of the effects of regulatory changes (Berkman et al., 2011; Bowen and Khan, 2014).

Our paper is strongly related to a study by Armstrong et al. (2010), who find a positive market reaction to mandatory IFRS adoption, especially for firms with lower information quality and higher information asymmetry in the pre-adoption period. Armstrong et al. (2010) also report an even stronger (and positive) reaction for banks with poor information quality, suggesting convergence benefits arising from IAS 39. However, Armstrong et al. (2010) consider announcements until November 2005, and therefore neglect the impact of announcements specifically related to IFRS 9 (which was issued in November 2009). In this paper, we aim to extend Armstrong et al. (2010), by examining how investors react to IFRS 9. This topic is important, because IFRS 9 is yet to be implemented, and the standard-setting process is still ongoing. ${ }^{1}$ Moreover, investors' expectations regarding IFRS 9 can now incorporate ex-post perceptions of the effects of the mandatory IFRS adoption, and thus our results could differ from those in Armstrong et al. (2010).

We analyse what country characteristics explain the cross-sectional variation in stock price reaction to the potential adoption of IFRS 9 using data for over 5,400 firms from 17 EU countries. We focus on the EU because it offers a unique setting: Mandatory adoption of IFRS rules for consolidated accounts of EU listed firms occurs for all countries in the same period. Our findings indicate that investors react positively to the ongoing accounting reform, especially for firms domiciled in countries with a weak rule of law and a small divergence between local accounting standards and IAS $39 .^{2}$ We estimate that the market reaction to an increase in the likelihood of the replacement of IAS 39 with IFRS 9 produces a total cumulative abnormal return of around $10 \%$. Even after controlling for potential confounding events and the extent of media coverage for each event, the total cumulative return is above $4 \%$. These findings bear important policy implications, because they constitute a first attempt at measuring the potential benefits and costs of implementing IFRS 9.

We are aware of the controversy regarding the ability of changes in external financial reporting quality to impose first-order effects on firm value (Zimmerman, 2013). However, it is an empirical question whether announcements regarding IFRS 9 have been perceived by international investors as value-enhancing, due to improved transparency of financial accounts across different countries. For example, Chen et al. (2013) provide evidence of positive externalities of IFRS adoption: Improved disclosure quality leads to higher investment efficiency.

\footnotetext{
${ }^{1}$ IASB divided the IFRS 9 project into three phases: 1. Classification and measurement; 2 . Amortized cost and impairment; 3 . Hedge accounting. IASB has postponed the mandatory date for adoption of IFRS 9 (which originally was set to be on 1 January 2013) to a future date.

${ }^{2}$ Note that, unlike Ding et al. (2007), who investigate the divergence between domestic accounting standards and international accounting standards as a whole, we focus specifically on divergence between domestic accounting standards and IAS 39.
} 
In our econometric analysis, as suggested by Zimmerman (2013), we very carefully check that our results are not driven by endogeneity, omitted variables, or selection bias. First, we use the population of listed firms in the 17 EU countries under examination (the same countries investigated by Chen et al., 2013). This reduces considerably the possibility of sample selection bias. Second, we carefully screen the event windows for confounding events. Finally, we employ bootstrapping to ensure that our results are not driven by sampling error or data mining.

The remainder of this paper is organized as follows. Section 2 describes the data and methodology. Section 3 discusses the empirical results. Section 4 concludes the paper.

\section{Data and methodology}

All financial data items used in this study were obtained from Thomson Reuters Datastream and Amadeus Bureau van Dijk databases. Table 1 reports the sample composition in terms of country of origin of the firms examined.

[TABLE 1: Sample composition by country]

To select the events, we start from 15 July 2009 (the day after a proposal by IASB to improve financial instruments accounting - IASB, 2009), and we consider events until 31 December 2012. We select event dates that refer exclusively to official announcements and initiatives by IASB and European Financial Reporting Advisory Group (EFRAG). Such announcements bear a strong influence on debates in the media regarding IFRS 9. We find 20 such events: The first event occurs when IASB issues IFRS 9, on November 12, 2009 (IASPlus, 2009). The last event takes place on November 28, 2012. Then, we further investigate the extent to which these events convey significant information to the market, by carefully searching in major international accounting and business media news related to each of the 20 announcements. We find substantial international media coverage in the week of the event for 13 of the 20 events originally included in our analysis. ${ }^{3}$ Tables 2 and 3 report all 20 events (both with and without media coverage), and a description of the variables under examination, respectively. In the subsequent econometric analysis, we include only the 13 events with media coverage in the estimation of the market reaction to IFRS 9. We assess 11 events as increasing the likelihood of IFRS 9 adoption according to the original schedule, and two events as decreasing it. These two events occur on April 8, 2011, and August 4, 2011. In the first case, EFRAG expresses concerns on the IASB-Supplementary Document Financial Instruments: Impairment, because of the proposal to set a floor for credit losses provisions, and calls the IASB to clarify aspects of the revised impairment model and to conduct field-testing, prior to issuing the final standard. Subsequently, on August 4, 2011,

\footnotetext{
3 We use the following websites: Financial Times, Bloomberg, Reuters, Wall Street Journal, Iasplus.com, IFRS.com and CFO.com. We employ a variety of keyword searches to assess the international press coverage of 20 events selected in the first stage of the selection process. In particular, we use the following keywords: "IFRS 9", "Accounting for financial instruments", "IAS 39”, "IAS 39 reform”, “IASB accounting reform”.
} 
IASB indicates its intention to postpone the mandatory effective date of IFRS 9 previously set to take place on January $1,2013 .^{4}$

Therefore, both these events are associated with a decrease in the likelihood of IFRS 9 adoption according to the original schedule.

\section{[TABLE 2: IFRS 9 events]}

\section{[TABLE 3: Variables description]}

After identifying the relevant event dates, we implement our event study.

First, we estimate the average market reaction to the regulation. Following Armstrong et al. (2010), we calculate, for each event, the difference between the 3day log return of a market-value weighted portfolio comprising the 5,480 firms in our sample and the log return of the proxy for the market portfolio (DJ STOXX Global 1800 Index Ex Europe). This proxy comprises the 1,800 world largest international firms excluding the European firms in the index (Armstrong et al., 2010). Then, we test whether the average 3-day market-adjusted returns (MARs) are significant. Similar to Armstrong et al. (2010), we multiply by minus one the MAR for events with a negative effect on the likelihood of IFRS 9 adoption.

Second, we measure the impact of three country-specific institutional factors (see Table 3): Rule of law, Divergence, and Public enforcement. First, we rank each country in terms of each of these institutional factors. ${ }^{5}$ Then, we construct marketvalue weighted portfolios of firms located in countries in the upper and lower portion of the distribution, and we calculate the 3-day MAR for each of these two portfolios. ${ }^{6}$ For convenience, we name the portfolio of firms in countries in the upper part of the ranking 'high' portfolio, and the portfolio of firms in the lower part of the ranking, 'low' portfolio. To extrapolate the impact of the institutional factors on the price reaction, we estimate the difference between the 3-day MAR for the 'high' and 'low' portfolios for each institutional factor (difference-in-MAR, henceforth DMAR). ${ }^{7}$ This technique produces the MAR of a trading strategy where we are long on firms in highranked countries and short on firms in low-ranked countries, for each institutional

\footnotetext{
${ }^{4}$ For the $12^{\text {th }}$ event in the original list of 20 events: "EFRAG does not support the proposals in relation to the "floor", and urges the IASB to clarify the objectives of the revised impairment model and to field test the proposals prior to finalising the standard." (EFRAG, 4/8/2011). For the $14^{\text {th }}$ event in the original list of 20 events: "The International Accounting Standards Board (IASB) published today for public comment an exposure draft of proposals to adjust the mandatory effective date of IFRS 9 Financial Instruments. The exposure draft proposes an effective date of 1 January 2015 (currently 1 January 2013) for IFRS 9.” (IASB, 8/4/2011).

${ }^{5}$ For Rule of law, which is time-varying, we perform the ranking for each year. For Divergence and Public enforcement, which are time-invariant, the ranking is the same for all periods.

${ }^{6}$ The three variables are significantly correlated, but they are far from being the same. The pairwise correlation coefficients are: $10.78 \%$ (Rule of law and Public enforcement), $31.91 \%$ (Rule of law and Divergence), and $15 \%$ (Divergence and Public enforcement).

${ }^{7}$ For example, in year 2009 the values for the variable Rule of law range from 0.3570 (Italy) to 1.9685 (Finland). The $95^{\text {th }}$ percentile of the distribution of Rule of law for 2009 is 1.9521 (corresponding to Sweden). Only firms in Finland have a larger value for Rule of law (1.9685, as said before). Therefore, all firms in Sweden and Finland will be considered in the 'high' portfolio for year 2009. The corresponding $5^{\text {th }}$ percentile for 2009 is 0.3570 (Italy), and no other country has a lower value for Rule of law in that year. Therefore, only Italian firms will be considered in the 'low' portfolio for 2009. For another example of this procedure, see Berkman et al. (2011).
} 
factor. In particular, we choose the $5^{\text {th }}$ and $95^{\text {th }}$ percentile of distribution as cut-off points, and for robustness we also report the results for the $10^{\text {th }}$ and $90^{\text {th }}$ percentile. $^{8}$ Comparing the MAR for firms in countries that are at the top and bottom of the rankings ensures that the countries in the two clusters are in fact different in terms of the institutional factor chosen. This increases the power of the test.

Finally, to give an indication of the overall impact of the reform, we also compute the sum of the 3-day MAR for all 13 events for which there is media coverage (3-day SMAR), and the sum of the difference-in-MARs for all 13 events (3day SDMAR). For the sake of brevity, we will henceforth refer to the statistics above as MAR, DMAR, SMAR, and SDMAR, since they are all calculated using a 3-day event window.

\section{Results}

In Table 4, we present the results for the MAR and SMAR for all the 5,480 firms in our sample (second column), and the DMAR and SDMAR based on the selected institutional factors. We also report the $1 \%$ and $5 \%$ bootstrapped critical values (for two-tailed tests) for the SMAR and SDMAR (the results for the critical values for the MAR and DMAR are the same, and are therefore not shown in the table). The bootstrapped critical values are based on 1,000 replications. For each replication, we select randomly 13 dates over the period from 15 July 2009 to 31 December 2012 (913 trading days). Panel A of Table 4 reports the results for the DMAR and SDMAR using the $5^{\text {th }}$ and $95^{\text {th }}$ percentile of the distribution of the institutional factors.

\section{[TABLE 4: Stock market reaction to IFRS 9 adoption events]}

The overall market reaction is positive and significant, suggesting that investors perceive the new regulation as having a positive impact on shareholder wealth. The average MAR is 0.0078 , significant at the $5 \%$ level. The SMAR is $10 \%$, or around $0.26 \%$ for each of the 39 days in the event window. ${ }^{9}$ The bootstrapped upper critical value for the SMAR at the 5\% significance level is $7.82 \%$. Therefore, the overall market reaction for the 13 events is statistically significant, and unlikely to be driven by pure fluke or data mining. While a precise estimation of the economic magnitude of shareholder wealth effects is difficult, a comparison of the estimated SMAR with those of 1,000 randomized samples suggests that such magnitude is far from

\footnotetext{
${ }^{8}$ For Public enforcement, using either set of cut-off points results in the same countries for the 'high' and 'low' portfolios. When we employ the $15^{\text {th }}$ and $85^{\text {th }}$ percentile as cut-off points, the results remain qualitatively the same. However, we do not report the results for the sake of brevity. The results are available upon request.

${ }^{9}$ In particular, the overall reaction to events number 12 and 14, associated with an expected decrease in the likelihood of the IFRS 9 adoption (see Table 2), is negative (-0.0155), while the overall reaction to the events associated with an expected increase in the likelihood of the IFRS 9 adoption is positive (0.0855). By multiplying by minus one the returns for events 12 and 14 , we obtain: $0.0855+0.0155=$ 0.101. For Rule of Law, the reaction to the "negative events" is positive ( 0.0005 for Panel A) and the reaction to the "positive events" is negative ( -0.0077 for Panel A): $-0.0077-0.0005=-0.0082$ (because of rounding-off error, this is slightly different from the result reported in Table 4: -0.0083). For Divergence, the reaction to the "negative events" is positive (0.0006) and the reaction to the "positive events" is negative (-0.0048): $-0.0048-0.0006=-0.0054$. For Public Enforcement, for which the results are insignificant, we obtain a negative reaction to both types of events: -0.0008 for the "negative events", and -0.0024 for the "positive events": $-0.0024+0.0008=-0.0016$. The results for Panel B of Table 4 are very similar, and are available upon request.
} 
negligible: Of the 1,000 random samples of fictitious events generated through bootstrap, only ten have a SMAR higher than $10 \%$. Moreover, the average SMAR for the 1,000 replications is $-1.20 \%$, the median $-1.19 \%$, and the maximum and minimum values for SMAR are $-18.88 \%$ and $12.12 \%$, respectively. Therefore, our results are not driven by our portfolio always outperforming the benchmark: on average, our portfolio underperforms the benchmark.

The results for the DMAR and SDMAR show a stronger market reaction for firms domiciled in countries with a low rule of law index (contrary to Armstrong et al., 2010), and for firms domiciled in countries where there is weaker divergence between local accounting standards and IAS 39. The results are significant at least at the 5\% level for both the average DMAR and the SDMAR. In particular, the SDMAR for Rule of law is -0.0083 while the $1 \%$ lower critical value is -0.0063 , and the SDMAR for Divergence is -0.0054 , while the $1 \%$ lower critical value is -0.0051 . Note that, for countries with high levels of Rule of law and Divergence, the results for both the average MAR and the SMAR are insignificant, suggesting that the announcements bear an impact only on firms in countries with weak Rule of law and a low Divergence index. The variable Public enforcement does not bear any effect on the reaction to IFRS 9 announcements. The results do not vary substantially when we consider the $10^{\text {th }}$ and $90^{\text {th }}$ percentile as cut-off points (Panel B of Table 4).

A possible limitation of an event study is that the estimation of the MAR may be affected by confounding events. For this reason, we have chosen a short event window, and we have focussed on events that have received attention from various international accounting and business media. Some of the events described in Table 2 are covered only by the IASPlus website: iasplus.com. Many studies in the accounting and finance literature identify this website as the most popular channel that disseminates relevant information on IAS/IFRS (Lagoarde-Segot, 2009; Larson and Street, 2011; Joos and Leung, 2013; Ramanna and Sletten, 2014). However, it is likely that these events did not impact the market substantially, and confounding events might have driven the price reaction. When we repeat the analysis after excluding the five events in Table 2 covered only by the IASPlus website, we obtain a much smaller (and more credible) result for the overall market reaction to the IFRS 9 adoption: $4.43 \%$ instead of $10.1 \%$. The results for the DMAR and SDMAR remain qualitatively the same, although their magnitude decreases. ${ }^{10}$

\section{Conclusions}

While much of the previous literature has examined the capital market effects around the compulsory adoption of IFRS, the literature on IFRS 9 is sparse. In this paper, we investigate the price reaction to news related to IFRS 9 adoption events. Our findings suggest that investors reacted positively to the ongoing accounting reform, particularly the shareholders of firms domiciled in countries with a weaker

\footnotetext{
${ }^{10}$ We thank an anonymous referee for this suggestion. To further address this issue, we have scoured major international outlets for possible confounding events that might affect the estimation of the MAR during the sample period using the LEXIS/NEXIS database. We have also exploited information reported in Deloitte's publication "Global Capital Markets Perspective for 2012". We have identified one important confounding event: the S\&P downgrade of the U.S. sovereign credit rating, on 5 August 2011 (the day after the event number 14). Excluding this event from the analysis reduces the overall market reaction from $10.1 \%$ to $8.16 \%$.
} 
rule of law (contrary to previous literature on IFRS adoption events) and weaker divergence between local accounting standards and IAS 39. These results indicate that investors are confident with the ability of IFRS 9 to address the problems inherent in IAS 39 implementation, but cross-country differences are to be expected. Because smaller divergence between local accounting standards and IAS 39 is associated with poorer firm-specific information (Ding et al., 2007), our findings suggest that better cross-country comparability outweighs the costs of poorer firm-specific information for countries for which divergence between domestic accounting standards and IAS 39 is relatively small. Empirical studies could follow after the final implementation of IFRS 9 to determine whether these expectations have been fulfilled, and if the market reaction depends on specific firm characteristics in addition to country factors. Finally, our results must be interpreted carefully, considering the limitations that affect any event study.

\section{Acknowledgements}

We are grateful to the editors Martin Loeb and Larry Gordon and two anonymous referees for their valuable comments and suggestions. We thank Klaus Schaeck and Giuseppe Sannino for helpful discussions. The usual disclaimer applies.

\section{References}

Armstrong, C., Barth, M., Jaqolinzer, A., Riedl, E., 2010. Market Reaction to the Adoption of IFRS in Europe. Account. Rev. 85 (1), 31-62.

Barth, M. E., Landsman, W. R., 2010. How did financial reporting contribute to the financial crisis? European Account. Rev.19 (3), 399-423.

Berkman, H., Cole, R. A., Fu, L. J., 2011. Political Connections and Minority-Shareholder Protection: Evidence from Securities-Market Regulation in China. J. Financ. Quantitative Analysis 45, 1391-1417.

Bowen, R., Khan, U., 2014. Market reactions to policy deliberations on fair value accounting and impairment rules during the financial crisis of 2008-2009. J. Account. Public Policy, forthcoming.

Chen, C., Young, D., Zhuang, Z., 2013. Externalities of Mandatory IFRS Adoption: Evidence from Cross-Border Spillover Effects of Financial Information on Investment Efficiency. Account. Rev. 88 (3), 881-894.

Christensen, H.B., Hail, L., Leuz, C., 2013. Mandatory IFRS Reporting and Changes in Enforcement. J. Account. Econ. 56, 147-177.

Dichev, I., Graham, J., Harvey, C., Rajgopal, S., 2014. Earnings quality: Evidence from the field. J. Account. Econ. 56, 1-33.

Ding, Y., Hope, O., Jeanjean, T., Stolowy, H., 2007. Differences between Domestic Accounting Standards and IAS: Measurement, Determinants and Implications. J. Account. Public Policy 26, 1-38.

Kaufmann, D., Kraay, A., Mastruzzi, M., 2011. The Worldwide Governance Indicators: Methodology and Analytical Issues. Hague J. Rule Law 3 (2), 220-246.

IASPlus (2009). IFRS 9 - Financial instruments. Available at: http://www.iasplus.com/en/standards/ifrs/ifrs9.

International Accounting Standards Board (2009). IASB proposes improvements to financial instruments accounting. IASB press release. 
Joos, P. P. M., Leung, E., 2013. Investor Perceptions of Potential IFRS Adoption in the United States. Account. Rev. 88 (2), 577-609.

Lagoarde-Segot, T., 2009. Financial reforms and time-varying microstructures in emerging equity markets. J. Bank. Financ. 33, 1755-1769.

La Porta, R., Lopez-de-Silanes, F., Shleiffer, A., Vishny, R., 1998. Law and finance. J. Polit. Econ. 106, 1113-1155.

La Porta, R., Lopez-de-Silanes, F., Shleifer, A., 2006. What Works in Securities Laws? J. Financ. 61 (1), 1-32.

Larson, R.K., Street, D.L., 2011. IFRS Teaching Resources: Available and Rapidly Growing. Account. Education: an International J. 20 (4), 317-338.

Laux, C., Leuz C., 2009. The crisis of fair-value accounting: making sense of the recent debate. Account. Organ. Soc. 34, 826-834.

Laux, C., Leuz, C., 2010. Did fair-value accounting contribute to the financial crisis? J. Econ. Perspectives 24 (1), 93-118.

Laux, C., 2012. Financial Instruments, Financial Reporting, and Financial Stability. Account. Bus. Res. 42 (3), 1-22.

Leuz, C., 2010. Different approaches to corporate reporting regulation: how jurisdictions differ and why. Account. Bus. Res. 30 (3), 229-256.

Nobes, C. (Ed.), 2001. GAAP 2001 - a survey of national accounting rules benchmarked against international accounting standards. I. Forum Account. Development (IFAD).

Paananen, M., Renders, A., Shima Kim, M., 2012. The Amendment of IAS 39 Determinants of Reclassification Behavior and Capital Market Consequences. J. Account., Auditing Finance 27(2), 208-235.

Ramanna, K., Sletten, E., 2014. Network Effects in Countries' Adoption of IFRS. The Account. Rev., forthcoming.

Schwert, G. W., 1981. Using financial data to measure effects of regulation. J. Law Econ. 24, 121-158.

Stigler, G. J., 1971. The theory of economic regulation. Bell J. Econ. Manag. Sci. 2, 3-21.

Zimmerman, J. L., 2013. Myth: External Financial Reporting Quality Has a First-Order Effect on Firm Value. Account. Horizons 27, 887-894. 
Table 1

Sample composition by country.

\begin{tabular}{ccc}
\hline & COUNTRY & FIRMS \\
1 & AUSTRIA & 71 \\
2 & BELGIUM & 152 \\
3 & DENMARK & 138 \\
4 & FINLAND & 112 \\
5 & FRANCE & 811 \\
6 & GERMANY & 999 \\
7 & GREECE & 223 \\
8 & IRELAND & 30 \\
9 & ITALY & 232 \\
10 & LUXEMBOURG & 11 \\
11 & NETHERLANDS & 100 \\
12 & NORWAY & 169 \\
13 & PORTUGAL & 55 \\
14 & SPAIN & 209 \\
15 & SWEDEN & 445 \\
16 & SWITZERLAND & 211 \\
17 & UNITED KINGDOM & 1,512 \\
\hline
\end{tabular}


Table 2

IFRS events.

\begin{tabular}{|c|c|c|c|c|}
\hline$N$. & Event date & Event description & $\begin{array}{c}\text { Probability } \\
\text { of adoption of IFRS } 9\end{array}$ & Media Coverage \\
\hline 1 & $11 / 12 / 2009$ & IASB issues IFRS 9 (completing the first phase - Classification and Measurement). & Increase & \begin{tabular}{|c|c|} 
iasplus.com/news \\
Financial Times.com \\
\end{tabular} \\
\hline 2 & 05/07/2010 & EFRAG releases the summary of the responses received on its outreach questionnaire published in March 2010. & - & Not coverage by international media \\
\hline 3 & $6 / 28 / 2010$ & $\begin{array}{l}\text { EFRAG releases the comment letter on the IASB Exposure Draft (ED) - Financial Instruments: Amortized Cost and } \\
\text { Impairment. }\end{array}$ & - & Not coverage by international media \\
\hline 4 & $7 / 16 / 2010$ & EFRAG releases the comment letter on the IASB Exposure Draft - Fair Value Option for Financial Liabilities. & Increase & iasplus.com/news \\
\hline 5 & 9/28/2010 & $\begin{array}{l}\text { EFRAG releases the comment letter on the FASB's ED Accounting for Financial Instruments and Revisions to the } \\
\text { Accounting for Derivative Instruments and Hedging Activities. }\end{array}$ & - & Not coverage by international media \\
\hline 6 & $10 / 28 / 2010$ & IASB issues additions to IFRS 9 for financial liability accounting, completing the classification and measurement phase. & Increase & Bloomberg.com/news \\
\hline 7 & $12 / 09 / 2010$ & IASB releases the Exposure Draft on accounting for hedging activities. & Increase & Financial Times.com \\
\hline 8 & $1 / 13 / 2011$ & $\begin{array}{l}\text { IASB and FASB publish a joint proposal approach on credit impairment of loans and other financial assets managed in an } \\
\text { open portfolio. }\end{array}$ & Increase & iasplus.com/news \\
\hline 9 & $1 / 31 / 2011$ & $\begin{array}{l}\text { IASB and FASB publish common proposal for accounting for impairment of financial assets such as loans managed in an } \\
\text { open portfolio. }\end{array}$ & Increase & Reuters.com/news \\
\hline 10 & $03 / 04 / 2011$ & $\begin{array}{l}\text { EFRAG recommends that IASB and FASB agree on a joint timetable to finalize accounting standard for financial } \\
\text { instruments. }\end{array}$ & Increase & iasplus.com/news \\
\hline 11 & 03/11/2011 & $\begin{array}{l}\text { EFRAG releases final comment letter to IASB in response the Exposure Draft on hedge accounting issued in December } \\
2010 .\end{array}$ & - & Not coverage by international media \\
\hline 12 & 04/08/2011 & $\begin{array}{l}\text { EFRAG releases the final comment letter to IASB in response to Supplementary Document Financial Instruments: } \\
\text { Impairment issued on } 31 \text { January } 2011 .\end{array}$ & Decrease & iasplus.com/news \\
\hline 13 & $05 / 10 / 2011$ & EFRAG releases summary of feedback received in outreach activity on the IASB's Supplementary Document. & - & Not coverage by international media \\
\hline 14 & $08 / 04 / 2011$ & IASB proposes adjustments to effective date of IFRS 9 from January 1, 2013 to January 1, 2015. & Decrease & $\begin{array}{l}\text { iasplus.com/news; } \\
\text { IFRS.com/news }\end{array}$ \\
\hline 15 & 10/28/2011 & $\begin{array}{l}\text { EFRAG releases final comment letter on the IASB's adjustments to mandatory effective date of IFRS } 9 \text { of January 1, } \\
2015 .\end{array}$ & - & Not coverage by international media \\
\hline 16 & 12/16/2011 & IASB releases amendments to IFRS 9 that defer the mandatory effective date from 1 January 2013 to 1 January 2015. & Increase & $\begin{array}{l}\text { iasplus.com/news; } \\
\text { IFRS.com/news }\end{array}$ \\
\hline 17 & $1 / 27 / 2012$ & $\begin{array}{c}\begin{array}{c}\text { IASB and FASB inform on the joint intention to reduce differences in classification and measurement models for financial } \\
\text { instruments. }\end{array} \\
\end{array}$ & Increase & $\begin{array}{c}\text { iasplus.com/news } \\
\text { Financial Times.com } \\
\end{array}$ \\
\hline 18 & $7 / 27 / 2012$ & EFRAG communicates new composition of the Working Group effective for financial instruments. & - & Not coverage by international media \\
\hline 19 & $09 / 07 / 2012$ & IASB releases draft of forthcoming general hedge accounting requirements that will be added to IFRS 9. & Increase & $\begin{array}{l}\text { Wall street journal.com/news; } \\
\text { Cfo.com/news }\end{array}$ \\
\hline 20 & $11 / 28 / 2012$ & IASB releases proposal for limited changes to IFRS 9 classification and measurement requirements. & Increase & iasplus.com/news \\
\hline
\end{tabular}


Table 3

Variables description.

\begin{tabular}{|c|c|c|}
\hline Variables & Measurement & Source \\
\hline Rule of law & $\begin{array}{l}\text { This variable captures the degree to which agents trust the } \\
\text { rules of society, as well as quality of contract enforcement, } \\
\text { property rights, police, and the courts. }\end{array}$ & Kaufmann et al. (2011) \\
\hline Divergence & $\begin{array}{l}\text { Similar to Ding et al. (2007), we obtain this variable from } \\
\text { the GAAP } 2001 \text { survey. This variable measures the extent } \\
\text { to which rules for the same item differ between domestic } \\
\text { accounting standards and IAS } 39 \text {. }\end{array}$ & Nobes (2001) \\
\hline Public enforcement & $\begin{array}{l}\text { The arithmetic mean of: Supervisor characteristic index, } \\
\text { investigative power index, orders index, and criminal } \\
\text { index, as defined in La Porta et al. (2006). }\end{array}$ & La Porta et al. (2006) \\
\hline
\end{tabular}


Table 4

Stock market reaction to IFRS 9 adoption events.

PANEL A

\begin{tabular}{|c|c|c|c|c|c|c|c|c|c|c|}
\hline & \multirow{2}{*}{\begin{tabular}{|c|} 
Market reaction \\
3-day MARs \\
\end{tabular}} & \multicolumn{3}{|c|}{ Rule of law } & \multicolumn{3}{|c|}{ Divergence } & \multicolumn{3}{|c|}{ Public enforcement } \\
\hline & & $A(H i g h)$ & $B($ Low $)$ & $A-B(D M A R)$ & $A(H i g h)$ & $B($ Low $)$ & $A-B(D M A R)$ & $A(H i g h)$ & $B(L o w)$ & $A-B(D M A R)$ \\
\hline & & \multicolumn{9}{|c|}{ Cut-off points: 5th and 95th percentile } \\
\hline Sum of MAR & $0.1010 * *$ & 0.0010 & $0.0092 * * *$ & $-0.0083 * * *$ & 0.0046 & $0.0103 * * *$ & $-0.0054 * * *$ & 0.0153 & $0.0167 * *$ & -0.0015 \\
\hline Average MAR & 0.0078 & 0.0001 & 0.0007 & -0.0006 & 0.0004 & 0.0008 & -0.0004 & 0.0012 & 0.0013 & -0.0001 \\
\hline $\begin{array}{c}\text { Standard } \\
\text { Deviation MAR }\end{array}$ & 0.0109 & 0.0008 & 0.0008 & 0.0007 & 0.0009 & 0.0008 & 0.0007 & 0.0021 & 0.0019 & 0.0011 \\
\hline t-stat & $2.5591 * *$ & 0.3396 & $3.1509 * * *$ & $-3.1062 * * *$ & 1.3926 & $3.5503^{* * *}$ & $-2.1852 * *$ & $1.9879 *$ & $2.4058 * *$ & -0.3635 \\
\hline p-value & 0.0238 & 0.7396 & 0.0077 & 0.0083 & 0.1871 & 0.0036 & 0.0478 & 0.0683 & 0.0317 & 0.7221 \\
\hline
\end{tabular}

Critical values for SMAR and SDMAR: Two-tailed tests based on bootstrapping technique with 1,000 replications

\begin{tabular}{|c|c|c|c|c|c|c|c|c|c|c|}
\hline Total Q(995) & 0.1135 & 0.0058 & 0.0079 & 0.0073 & 0.0070 & 0.0085 & 0.0066 & 0.0222 & 0.0214 & 0.0090 \\
\hline Total Q(975) & 0.0782 & 0.0040 & 0.0056 & 0.0053 & 0.0053 & 0.0066 & 0.0055 & 0.0169 & 0.0153 & 0.0067 \\
\hline Total Q(25) & -0.1074 & -0.0053 & -0.0078 & -0.0044 & -0.0061 & -0.0088 & -0.0038 & -0.0250 & -0.0172 & -0.0130 \\
\hline Total Q(5) & -0.1534 & -0.0086 & -0.0111 & -0.0063 & -0.0099 & -0.0119 & -0.0051 & -0.0350 & -0.0242 & -0.0168 \\
\hline
\end{tabular}

Countries in upper and lower part of the distribution for Rule of law, Divergence, and Public enforcement

Countries in

'high' and 'low'

portfolios

\begin{tabular}{|c|c|c|c|c|c|}
\hline Finland, Sweden & Greece, Italy & Sweden & $\begin{array}{l}\text { Ireland, The } \\
\text { Netherlands, } \\
\text { Norway }\end{array}$ & France & $\begin{array}{l}\text { Austria, } \\
\text { Belgium, } \\
\text { Germany }\end{array}$ \\
\hline
\end{tabular}

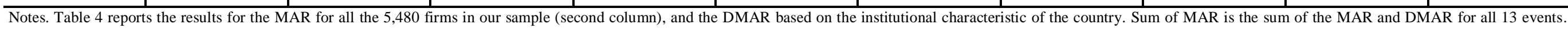

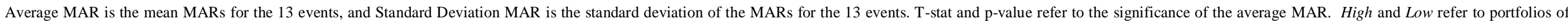

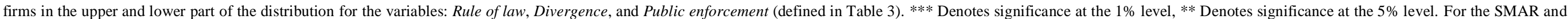
SDMAR, the significance is assessed by comparing the estimated statistic with the critical value obtained through bootstrap simulations. 


\section{Table 4 continued}

\section{PANEL B}

\begin{tabular}{|c|c|c|c|c|c|c|c|c|c|}
\hline & \multicolumn{3}{|c|}{ Rule of law } & \multicolumn{3}{|c|}{ Divergence } & \multicolumn{3}{|c|}{ Public enforcement } \\
\hline & $A($ High $)$ & $B(L o w)$ & $A-B(D M A R)$ & $A($ High $)$ & $B(L o w)$ & $A-B(D M A R)$ & $A($ High $)$ & $B($ Low $)$ & $A-B(D M A R$ \\
\hline & \multicolumn{9}{|c|}{ Cut-off points: 10 th and 90 th percentile } \\
\hline Sum of MAR & $0.0055^{* *}$ & $0.0181 * * *$ & $-0.0126 * * *$ & 0.0063 & 0.0200 & $-0.0135 * * *$ & 0.0153 & 0.0167 & -0.0015 \\
\hline Average MAR & 0.0004 & 0.0014 & -0.0010 & 0.0005 & 0.0015 & -0.0010 & 0.0012 & 0.0013 & -0.0001 \\
\hline Standard & 00012 & 00018 & 00018 & م مO10 & ( 0014 & $\Omega 0 \cap 11$ & 1 1 & 00010 & ค $\cap 011$ \\
\hline t-stat & 1.1625 & $2.7879 * *$ & $-1.9766 *$ & 1.6987 & 3.8331 & $-3.3522 * * *$ & 1.9879 & 2.4058 & -0.3635 \\
\hline \multirow[t]{2}{*}{ p-value } & 0.2659 & 0.0154 & 0.0697 & 0.1132 & 0.0021 & 0.0052 & 0.0683 & 0.0317 & 0.7221 \\
\hline & \multicolumn{9}{|c|}{ Critical values for SDMAR: Two-tailed tests based on bootstrapping technique with 1,000 replications } \\
\hline Total Q(995) & 0.0058 & 0.0111 & 0.0118 & 0.0085 & 0.0163 & 0.0140 & 0.0222 & 0.0214 & 0.0090 \\
\hline Total Q(975) & 0.0040 & 0.0077 & 0.0100 & 0.0062 & 0.0116 & 0.0103 & 0.0169 & 0.0153 & 0.0067 \\
\hline Total Q(25) & -0.0053 & -0.0138 & -0.0057 & -0.0077 & -0.0167 & -0.0073 & -0.0250 & -0.0172 & -0.0130 \\
\hline Total Q(5) & -0.0086 & -0.0181 & -0.0081 & -0.0120 & -0.0220 & -0.0109 & -0.0350 & -0.0242 & -0.0168 \\
\hline
\end{tabular}

Countries in upper and lower part of the distribution for Rule of law, Divergence, and Public enforcement

\begin{tabular}{|c|c|c|c|c|c|c|c|}
\hline $\begin{array}{l}\text { Countries in } \\
\text { 'high' and 'low' } \\
\text { portfolios }\end{array}$ & $\begin{array}{c}\text { Denmark, } \\
\text { Finland, } \\
\text { Norway, Sweden }\end{array}$ & $\begin{array}{l}\text { Greece, Italy, } \\
\text { Portugal, Spain }\end{array}$ & $\begin{array}{l}\text { Denmark, } \\
\text { Sweden }\end{array}$ & \begin{tabular}{|} 
Austria, Ireland, \\
Italy, The \\
Netherlands, \\
Norway
\end{tabular} & France & $\begin{array}{l}\text { Austria, } \\
\text { Belgium, } \\
\text { Germany }\end{array}$ & \\
\hline
\end{tabular}


